Brit. F. vener. Dis. (1969), 45, 200.

\title{
ERYTHROMYCIN IN EARLY SYPHILIS*
}

\author{
BY
}

\author{
W. L. FERNANDO
}

V.D. Clinic, Colombo, Ceylon

Keller and Morton (1953) first discovered the treponemicidal properties of erythromycin and Turner and Schaeffer (1954) showed that erythromycin came second to penicillin as the most active antibiotic against Treponema pallidum. Kolmer and Rule (1956) attributed treponemicidal properties to erythromycin, but obtained superior results with several other antibiotics. Alexander and Schoch (1954) treated four cases of early syphilis with erythromycin and observed the rapid disappearance of Treponema pallidum from the lesions, noting that the lesions healed as promptly as with other drugs. Montero (1956) treated 27 cases of early syphilis with erythromycin (9-12 g.) with satisfactory results, and Montgomery and Knox (1959) obtained encouraging results in forty cases using a similar dosage. Gertler (1961) treated twelve patients with early syphilis using 1-1.6 g. of erythromycin daily for 15-20 days (follow-up period 7 months) and concluded that erythromycin had a place in the treatment of those allergic to penicillin. Montgomery, Knox, Sciple, and Vanderstoep (1961) treated 148 cases of dark-field positive syphilis with different schedules of erythromycin, and concluded that $20 \mathrm{~g}$. spread over 10 days might prove satisfactory, but that $10 \mathrm{~g}$. over 10 days was not adequate and 9-10 g. over 3-5 days was unsatisfactory. Greaves (1961) treated 29 cases of early syphilis and seventeen completed treatment and follow-up with a cerebrospinal fluid examination. He concluded that the results obtained with erythromycin were not comparable to those obtained with the usual dose of penicillin, but he used only a total dose of $10 \mathrm{~g}$. in an 8-day course of treatment. Moore, Vander Stoep, Knox and Montgomery (1962) treated 130 dark-field positive cases of primary and secondary syphilis using three schedules of treatment, and found good results in those given $500 \mathrm{mg}$. three times a day for 10 days and $500 \mathrm{mg}$. 6-hrly for 10

^Received for publication January 15, 1969. days, but in those given $250 \mathrm{mg}$. 6-hrly for 10 days the results were unsatisfactory. Wojtkiewiczowa and Toruniowa (1965) treated 58 cases of early syphilis with $2 \mathrm{~g}$. daily for 10 days and observed that erythromycin could be recommended in early syphilis as a substitute for penicillin in penicillinsensitized patients. Lucas and Price (1967), in a co-operative evaluation of treatment for early syphilis, concluded that a total dose of $20 \mathrm{~g}$. erythromycin was not adequate for the treatment of early syphilis but that a body-weight analysis suggested that a $30 \mathrm{~g}$. dosage would be effective. The dosage of erythromycin recommended by the U.S. Public Health Service (USPHS, 1960) was 20-30 g. given over 10 to 15 days.

\section{Material and Methods}

Erythromycin is the drug of choice at this clinic for the treatment of early syphilis when patients are sensitive to penicillin. 34 patients have been treated, of which six were cases of sero-negative primary syphilis, fourteen of sero-positive primary syphilis, and thirteen of secondary syphilis; there was one case of early latent infection.

All patients at this clinic are given a skin test for penicillin sensitivity before penicillin is given and in 31 of the 34 cases there had been a positive reaction, while in three a sensitivity reaction had developed after the first injection of PAM (procaine penicillin with 2 per cent. aluminium monostearate). The dose of erythromycin given to these patients (whose average weight was about $120 \mathrm{lb}$.) was $500 \mathrm{mg}$. 6 -hrly for 10 days, i.e. a total dosage of 20 ' $\mathrm{g}$. Six of these patients had only 8 days' treatment.

Usually sufficient capsules are given to the patient to last 2 to 3 days, after which he should re-attend regularly to be issued with a supply of the drug for 2 to 3 day periods until the treatment is completed. After the lesions have healed, he is followed at monthly intervals, with a clinical examination and a VDRL blood test. Tests of the cerebrospinal fluid are carried out after one year. 


\section{Results}

It was observed that in almost all cases the lesions had healed before the treatment was completed. Only one patient, a case of sero-positive primary syphilis, complained of diarrhoea with blood and mucus after the treatment was over; his lesions had all healed by this time.

The periods of follow-up of the 34 patients are tabulated below.

All six cases of sero-negative primary syphilis continued to be sero-negative after treatment. One case became sero-positive at the second month, but became sero-negative at the next month and continued so. Of the fourteen sero-positive cases, ten became sero-negative after treatment: four at one month and one each after $2,3,4,5,8$, and 9 months respectively. The remaining four were still seropositive at the end of the follow-up period of 2, 14, 16 , and 18 months respectively.

Of the thirteen cases of secondary syphilis, seven became sero-negative after treatment at 3 months ( 2 cases), and one each at $4,5,9,11$, and 18 months respectively. Six were sero-positive at the end of the follow-up period of 1 month, 3, 7, 8, 10, and 13 months.

The only case of early latent syphilis was positive at the end of the follow-up period of 4 months after treatment.

\section{Cerebrospinal Fluid Examination}

Seven of these patients had a cerebrospinal fluid examination after treatment; they comprised one case of sero-negative and two of sero-positive primary syphilis and four cases of secondary syphilis. Lumbar punctures were performed: 2 years after treatment in four cases, 21 months after treatment in one case, and 16 months after treatment in two. The cerebrospinal fluid was normal in all cases. The examination included a VDRL test, and the VDRL result in the blood of these patients was negative at the time of the lumbar puncture in all these cases.

\section{Summary}

34 patients with early syphilis treated with erythromycin $500 \mathrm{mg}$. 6-hrly for 10 days, i.e. a total of $20 \mathrm{~g}$. (the average weight of the patients being $120 \mathrm{lb}$.), were followed up for varying periods- four for over 24 months, seventeen for over 12 months, 22 for over 7 months, 29 for over 3 months, etc. Of these, seven underwent cerebrospinal fluid examination at least 16 months after treatment, with normal results in all cases. There was no evidence of relapse in any of these cases. The results were found to be quite satisfactory and encouraging.

\section{REFERENCES}

Alexander, L. J., and Schосн, A. G. (1954). Amer. F. Syph., 38, 107.

GeRTLER, W. (1961). Derm. Wschr., 143, 220.

Greaves, A. B. (1961). Publ. Hlth Rep. (Wash.), 76, 929.

Keller, R., and Morton, H. E. (1953). Amer. F. Syph., 37, 379.

Kolmer, J. A., and RULE, A. M. (1956). In "Antibiotics Annual, 1955-56", ed. H. Welch and F. MartiIbanez, p. 592. Medical Encyclopedia Inc., New York.

LUCAS, J. B., and PRICE, E. V. (1967). Brit. F. vener. Dis., 43, 244.

MONTERO, O. (1956). "I International Symposium on Venereal Diseases and Treponematoses", Washington D.C., May 28-June 1.

MONTGOMERY, C. H., and KNOX, J. M. (1959). A.M.A. Arch. Derm., 80, 205.

- - - Sciple, G. W., and Vander Stoep, E. M. (1961). Arch. intern. Med., 107, 732.

Moore, M. B., JR., VANDer Stoep, E. M., KNox, J. M., and Montgomery, C. H. (1962). F. invest. Derm., 38, 285.

TURNER, T. B., and Schaeffer, K. (1954). Amer. $\mathcal{F}$. Syph., 38, 81.

United States Public Health Service (1960). "Syphilis: Modern Diagnosis and Management", U.S. Dept. of Health Education and Welfare, Washington, D.C.

WojtKIEWICZOWA, J., and TORUNIOWA, B. (1965). Przegl. Derm., 52, 479.

\section{L'érythromycine dans la syphilis récente Résumé}

34 malades (poids moyen: $54 \mathrm{~kg}$.) atteints de syphilis récente et traités par l'érythromycine- $500 \mathrm{mg}$. toutes les $6 \mathrm{~h}$. pendant 10 jours, soit un total de $20 \mathrm{~g}$.- furent suivis des temps variés: 4 plus de 24 mois; 17 plus de 12 mois; 22 plus de 7 mois; 29 plus de 3 mois, etc. Parmi eux, sept ont eu, au moins 16 mois après le traitement, un examen du liquide céphalorachidien avec des résultats normaux dans tous les cas. Les résultats sont considérés comme tout-à-fait satisfaisants et encourageants.

\begin{tabular}{l|rrr|rrrrr|rrrrr|rr|r|r|r|}
\hline Months & 1 & 2 & 3 & 4 & 5 & 6 & 7 & 8 & 9 & 10 & 11 & 12 & 13 & 14 & 15 & 16 \\
\hline No. of patients & 34 & 30 & 29 & 26 & 22 & 22 & 22 & 22 & 21 & 21 & 17 & 17 & 15 & 13 & 12 & 12 \\
\hline Months & 17 & 18 & 19 & 20 & 21 & 22 & 23 & 24 and over & & & & \\
\hline No. of patients & 10 & 9 & 7 & 7 & 7 & 5 & 5 & 4 & & & & & & \\
\hline
\end{tabular}

